\title{
Growth Performance, Carcass Characteristics and Meat Quality of Finishing Bulls Fed Crude Glycerin- Supplemented Diets
}

\author{
Mônica Chaves Françozo ${ }^{1}$, Ivanor Nunes do Prado ${ }^{1 *}$, Ulysses Cecato ${ }^{1}$, Maribel Velandia \\ Valero $^{1}$, Fernando Zawadzki ${ }^{1}$, Ossival Lolato Ribeiro ${ }^{1}$, Rodolpho Martin do Prado ${ }^{1}$ and \\ Jesuí Vergílio Visentainer ${ }^{2}$ \\ ${ }^{I}$ Departamento de Ciências Animal; Universidade Estadual de Maringá; ${ }^{2}$ Departamento de Química; Universidade \\ Estadual de Maringá; Maringá - PR - Brasil
}

\begin{abstract}
This study was conducted to evaluate the performance, carcass characteristics and chemical composition of Longissimus muscle (LM) of the bulls. Twenty-four Nellore bulls were used in a complete randomised design. The bulls were randomly assigned to one of the three diets containing 0, 5 or $12 \%$ glycerin. Final BW and ADG were similar $(P>0.05)$ between the bulls fed with 5 or $12 \%$ of glycerin but were higher $(P<0.10)$ compared to the bulls fed without glycerin. DMI and feed efficiency was not affected $(P>0.05)$ by glycerin level. Hot carcass weight increased $(P<0.10)$ when glycerin was fed at 5\%. Glycerin level did not affect $(P<0.05)$ the dressing percentage and fat thickness. LM increased $(P<0.10)$ when glycerin was fed at $12 \%$. Dietary glycerin did not affect $(P>0.05)$ the conformation, colour, texture, marbling and $\mathrm{pH}$. There was difference $(P>0.05)$ for moisture, ashes and crude protein among glycerin levels. Bulls fed $12 \%$ glycerin present the highest $(P<0.03)$ total lipids on LM. The percentage of saturated fatty acids (SFA), monounsaturated acids (MUFA), polyunsaturated acids (PUFA), $n-6$ and $n-3$ fatty acids and PUFA/SFA and n-6:n-3 ratios of the LM were similar among the diets. In conclusion, glycerin level did not affect the animal performance and carcass characteristics of Nellore bulls finished in feedlot.
\end{abstract}

Key words: cattle, fat, glycerin, human health, silage corn

\section{INTRODUCTION}

Because of the rising corn costs, alternative feed sources have become a major focus for the livestock industry (Moreira et al. 2003; Prado et al. 2003; Abrahão et al. 2005; 2006; Prado et al. 2008b). In Brazil, the biodiesel industry has emerged; its production helps to conserve the environment by reducing global warming gases and also contributes to social development through the generation of jobs (Oliveira et al. 2006). Biodiesel is a biodegradable fuel derived from renewable sources that can be obtained by different processes such as cracking, esterification or transesterification. Glycerin is the main coproduct generated in the production of biodiesel at approximately 10 to $13 \%$ of the total volume of biodiesel produced (Dasari et al. 2005). Glycerin is produced as a result of transesterification of triglycerides with alcohol and has impurities such as water, salts, esters, alcohol, and residual oil, which give it low value (Ooi et al. 2004). Trabue et al. (2007) reported that the rumen metabolises about $80 \%$ of glycerin after $24 \mathrm{~h}$ of intake. The

*Author for correspondence: inprado@uem.br 
fermentation of glycerin by rumen microbes provides high levels of volatile fatty acids (mainly propionate and butyrate) that could be used as the main energy sources for the animal. Apparently, glycerin present in the rumen is metabolised as a carbohydrate, and when formulated into a diet of high forage for dairy cows and the estimated value of net energy for lactation (ELL) of the glycerin has been from 1.98 to $2.27 \mathrm{Mcal} / \mathrm{kg}$ (Hippen et al. 2008). Schröder and Südekum (1999) estimated this from 1.98 to $2.26 \mathrm{Mcal} / \mathrm{kg}$ for ruminant diets and concluded that glycerin could be included in the diets for ruminants up to $10 \%$ of the DM as a rapid-fermentation energy source. Donkin (2008) reported an increase in body weight of dairy cows fed with the diets containing 10 or $15 \%$ glycerin. Parsons et al. (2009) observed no difference for dry matter conversion when glycerin was up to $2 \%$ of the diet and also found that the inclusion of 4,8 , 12 and $16 \%$ glycerin resulted in a linear decrease in the intake by the crossbred heifers. Elam et al. (2008) used 156 heifers and found that the feedlot performance was slightly reduced with an increase in the level of crude glycerin in the diet (7.5 or $15 \%$ on DM basis). The reductions in the performance were directly related to linear decrease in dry matter intake. Elam et al. (2008) aimed to compare the substitution of the flaked corn by glycerin (10\% of DM) in the finishing diet and suggested that glycerin could be metabolised in the rumen as a unit of three carbons, and thus modify the behaviour. These authors used 72 crossbred Charolais vs. Hereford and observed no difference in DMI, ADG and FC as a result of the treatments. However, there is a clear difference in feeding behaviour because the animals that received the treatment containing glycerin need more time to consume food than the diets without glycerin. Parsons et al. (2009) observed an increase on final body weight of $12.7,8.1$ and 5.3 $\mathrm{kg}$ when glycerin composed 2, 4 or $8 \%$ of the diet of crossbred heifers. Mach et al. (2009) used 48 Holstein bulls and evaluated three levels of glycerin $(0,4$ or $12 \%$ on DM basis) and observed that DMI, ADG and starch intake were not affected by the glycerin level in the diet.

Elam et al. (2008) evaluated the addition of crude glycerin $(0,7.5$ and $15 \%$ on DM basis) and found no difference in the carcass characteristics such as hot carcass weight, dressing percentage, body fat, Longissimus muscle, visceral fat and marbling. Mach et al. (2009) assessed the effects of the levels of glycerin in the bulls' diet on carcass characteristics and meat quality and observed that the dietary treatments $(0,4$ or $12 \%)$ did not affect the hot carcass weight, dressing percentage, fat thickness or conformation. They also found that the Longissimus muscle and intramuscular fat were not affected by the treatments. However, levels of 12 or $16 \%$ resulted in a decrease of 1.9 and $14.3 \mathrm{~kg}$, respectively. They concluded that the inclusion up to $8 \%$ glycerin in the diet could effectively increase the final body weight and hot carcass weight in the finishing bulls. For evaluation on Longissimus muscle in the same survey, they found a significant increase on Longissimus muscle (at 2\%) but a linear reduction in the inclusion of other levels. Previous studies have suggested that glycerin could be an effective feed source in multiple species. However, there are limited data showing the effect of glycerin on beef cattle performance, carcass characteristics and meat quality.

The aim of this study to determine the effects of feeding different glycerin levels as an energy source on the animal performance, carcass characteristics and meat quality of Nellore bulls finished in feed-lot.

\section{MATERIALS AND METHODS}

\section{Animals, Housing and Diets}

This experiment was approved by the Department of Animal Production, at the State University of Maringá (CIOMS/OMS, 1985). It was conducted at the JBS Farm Experimental Station at Colorado in the city of Colorado, Paraná, and South Brazil. Twenty-four Nellore bulls were used in a complete randomised design. Bulls were weighed and distributed in three diets. After arrival, the bulls were weighed and had an average initial BW of $380 \pm 7.6 \mathrm{~kg}$ and age of $24 \pm 2.2 \mathrm{mo}$. Glycerin was produced in a soy-diesel facility (BIOPAR, Rolândia, Paraná, Brazil South) and contained $81.2 \%$ glycerin, $0.33 \%$ methanol, $12.3 \%$ water, $0.10 \%$ crude protein, $0.30 \%$ crude fat, $4.76 \%$ salt, $1.16 \%$ sodium, $1,7 \%$ chloride, $0.08 \%$ potassium, $0.02 \%$ magnesium, 0.24 phosphorus and 3.400 kcal-kg gross energy.

Glycerin fed in the current study was used as an energetic ingredient; therefore, to obtain three isoenergetic diets, the increase in glycerin level was counterbalanced, mainly by a decrease in corn grain content (Table 1). All the diets were formulated to be isonitrogenous. The bulls were 
randomly assigned to one of the three diets containing 0,5 or $12 \%$ glycerin on DM basis. The bulls were fed concentrate and corn silage (Table
2) in separate troughs, both as ad libitum intake, until day 84 of the experiment when the bulls reached a final $\mathrm{BW}$ of $513 \pm 9.9 \mathrm{~kg}$.

Table 1 - Ingredients and chemical composition of the diets (\%).

\begin{tabular}{|c|c|c|c|c|c|c|c|c|c|c|}
\hline \multirow{2}{*}{ Ingredients } & \multirow[b]{2}{*}{ DM } & \multicolumn{7}{|c|}{ DM/\% } & \multirow[b]{2}{*}{ NFC } & \multirow[b]{2}{*}{ TDN } \\
\hline & & $\mathbf{C P}$ & $\mathbf{O M}$ & Ash & EE & NDF & ADF & TC & & \\
\hline Corn silage & 32.1 & 7.50 & 96.5 & 3.50 & 3.50 & 48.4 & 25.6 & 86.3 & 38.0 & 60.0 \\
\hline Corn grain & 88.9 & 9.93 & 96.1 & 3.90 & 3.50 & 17.7 & 4.40 & 86.6 & 68.9 & 90.0 \\
\hline Soybean meal & 88.6 & 49.5 & 93.7 & 6.70 & 0.50 & 13.7 & 6.00 & 43.5 & 29.8 & 82.0 \\
\hline Glycerin & 87.8 & 0.10 & & 4.76 & 0.30 & & & & & 90.0 \\
\hline Urea & 98.0 & 262 & & & & & & & & \\
\hline Limestone & 98.0 & & & 90.0 & & & & & & \\
\hline \multirow[t]{2}{*}{ Premix salt } & 98.0 & & & 90.0 & & & & & & \\
\hline & & & & & Diets & & & & & \\
\hline $\mathrm{G} 00^{1}$ & 47.0 & 11.6 & 95.0 & 4.55 & 3.31 & 32.8 & 15.1 & 83.3 & 50.5 & 73.3 \\
\hline $\mathrm{G} 05^{2}$ & 47.1 & 11.6 & 89.9 & 4.58 & 3.14 & 31.8 & 14.9 & 78.7 & 47.0 & 72.2 \\
\hline $\mathrm{G} 12^{3}$ & 47.0 & 11.5 & 79.9 & 4.69 & 2.67 & 30.0 & 14.4 & 69.3 & 39.4 & 72.9 \\
\hline
\end{tabular}

${ }^{1}$ Without glycerin; ${ }^{2} 5 \%$ glycerin; ${ }^{3} 12 \%$ glycerin.

Table 2 - Intake and performance of Nellore bulls finished in feedlot fed diets containing different glycerin level.

\begin{tabular}{|c|c|c|c|c|c|}
\hline \multirow[b]{2}{*}{ Item } & \multicolumn{5}{|c|}{ Dietary glycerin, DM/\% } \\
\hline & G00 $^{1}$ & $\mathbf{G 0 5}^{2}$ & $\mathbf{G 1 2}^{3}$ & SD $^{4}$ & $\mathbf{P}<\mathbf{F}^{5}$ \\
\hline Initial BW, kg & 408.8 & 408.9 & 408.3 & 7.63 & 0.92 \\
\hline Final BW, kg & $509.6 b$ & $517.9 \mathrm{a}$ & $515.4^{\mathrm{a}}$ & 9.92 & 0.08 \\
\hline $\mathrm{ADG}, \mathrm{kg}$ & $1.33 b$ & $1.43 \mathrm{a}$ & $1.40^{\mathrm{a}}$ & 9.92 & 0.08 \\
\hline Total DMI, kg/d & 11.3 & 12.2 & 11.1 & 0.32 & 0.22 \\
\hline Total DMI, \% BW & 2.46 & 2.44 & 2.45 & 0.09 & 0.93 \\
\hline $\mathrm{G}: \mathrm{F}$ & 0.22 & 0.20 & 0.22 & 0.02 & 0.91 \\
\hline
\end{tabular}

${ }^{1}$ Without glycerin; ${ }^{2} 5 \%$ glycerin; ${ }^{3} 12 \%$ glycerin; ${ }^{4}$ Standard deviation; ${ }^{5}$ Effect of glycerin level.

\section{Sample Collection}

The bulls' BW and concentrate and corn silage intakes were recorded monthly. The bulls were transported to the slaughterhouse after day 84 of the study. The truck stocking density was 1 animal $/ \mathrm{m}^{2}$, and the transport distance was $80 \mathrm{~km}$. At the slaughterhouse, the bulls were housed in collective pens for approximately $12 \mathrm{~h}$ (overnight) before slaughter. The bulls were slaughtered at a commercial slaughterhouse according to industrial practices in Brazil. Following the slaughter, the carcasses were identified, weighed and chilled for $24 \mathrm{~h}$ at $4^{\circ} \mathrm{C}$. After chilling, the right part of the carcass was used to determine the quantitative characteristics. Twenty-four hours later, Longissimus muscle samples were taken by a complete cross section between the $12^{\text {th }}$ and $13^{\text {th }}$ ribs. The fat was discarded and the muscle portion was frozen at $-20^{\circ} \mathrm{C}$ for further analysis.

\section{Carcass characteristics measurements}

Hot carcass weight (HCW) was determined soon after the slaughter and before carcass chilling.
Cold carcass weight (CCW) was determined after chilling overnight $\left(4^{\circ} \mathrm{C}\right)$. After chilling, the right part of the carcass was used to determine the CCW.

Hot carcass dressing (HCD). The percentage of individual animal dressing was defined by the ratio of HCW to live weight.

Drip loss (DL) was measured on approximately $100 \mathrm{~g}$ of LM removed 48 hours post mortem using the plastic method described by Honikel (1998). Drip loss is expressed as a percentage of the initial weight. Fat thickness (FAT) was measured by a calliper averaging three points between the $12^{\text {th }}$ and $13^{\text {th }}$ ribs the over the LM.

Longissimus muscle area (LMA). The right part of the carcass was measured after a cross-section cut was made between the $12^{\text {th }}$ and $13^{\text {th }}$ ribs using a compensating planimeter that measured the areas of objects with irregular shapes.

Carcass conformation (CON) was evaluated by Müller's point scale (Müller 1980) in which the highest value indicated the best conformation. The muscle development was considered after the exclusion of fat thickness. The CON is reported as 
superior, very good, good, regular, poor, or inferior; ratings may also be reported as plus, average, and minus. The carcass length was evaluated by the measurements taken from the skull board to the pubic bone on the anterior side of the first rib.

Colour (COL). The muscle colour after $24 \mathrm{~h}$ carcass chilling was analysed. Colouration was evaluated according to a point scale 30 minutes after a cross-sectional cut made on the Longissimus between the $12^{\text {th }}$ and $13^{\text {th }}$ ribs (Müller, 1980).

Texture (TEX) was determined through of the size of fascicle (muscular "grain" size) and evaluated subjectively on a point scale (Müller, 1980).

Marbling (MAR) was measured in the LM between the $12^{\text {th }}$ and $13^{\text {th }}$ ribs, following the scores described by Müller (1980).

$p H$. The $\mathrm{pH}$ of the meat was measured after chilling using a $\mathrm{pH}$ Meter Text Model (Tradelab, Contagem - MG, Brazil) as described by Lanara (1981).

Thawing loss. For the determination of water loss, samples were weighed after thawing At $2+20 \mathrm{C}$ and $24 \mathrm{~h}$ afterwards; it was determined by the loss on thawing. The loss on thawing is the ratio of sample weight before and after being frozen and multiplied by 100 .

Cooking loss. The samples of the meat were cut and weighed (initial weight). Individual standardised slices (50 $\mathrm{mm}$ thick) were placed in an electric oven. These samples were cooked to a defined internal temperature $\left(72^{\circ} \mathrm{C}\right)$. When the endpoint temperature was attained, the samples were removed from the electric oven and held in environmental conditions until equilibrated. The meat was then taken from the plates and weighed.

Colour values was measured on LM samples removed $48 \mathrm{~h}$ post mortem using a Minolta Chroma Meter CR-310 (Osaka, Japan) calibrated against a white tile $\left(\mathrm{L}^{*}=92: 30, \mathrm{a}^{*}=0.32\right.$ and $\mathrm{b}^{*}$ $=0.33)$. The samples were allowed to bloom for 1 $\mathrm{h}$ at $4^{\circ} \mathrm{C}$ prior to the measurements. The parameters $L^{*}, a^{*}$ and $b^{*}$, representing lightness, redness and yellowness, were measured on five sites of each LM, and the average was presented. Shear force. The sample was cut from a block of thawed or cooked meat and avoiding damage was cut on a $2.5 \mathrm{~cm}$ cross-section with the fibre direction parallel to the long dimension of a least 1 $\mathrm{cm}$. The sample was sheared at a right angle to the axis. The units of measurement were $\mathrm{kg} / \mathrm{cm}^{2}$. The shear force was measured perpendicular to the orientation of muscle fibres with a WarnerBratzler shear device, adapted to the model TA.XT Plus (Stable Mycro Systems, United Kingdom) (Bouton et al. 1971), regarded as the average of six readings of each sample. The samples were completely sheared and the speeds used were 5 $\mathrm{mm} / \mathrm{s}$ pre-and post-test and $2 \mathrm{~mm} / \mathrm{s}$ during the test.

\section{Chemical Analyses}

Laboratory analyses of meat were carried out two months after the sampling. The samples were thawed at room temperature $\left(20^{\circ} \mathrm{C}\right)$, grounded, homogenised, and analysed in triplicate. The beef moisture and ash contents were determined according to AOAC (1998). The crude protein content was obtained through the Kjeldahl method (AOAC 1998). Total lipids were extracted using the Bligh and Dyer (1959) method with a chloroform/methanol mixture. Fatty acid methyl esters (FAMEs) were prepared by triacylglycerin methylation according to the ISO (1978) method. The FAMEs were analysed in a gas chromatograph (Varian, USA) equipped with a flame ionisation detector and a fused silica capillary column CP-7420 (100 m, $0.25 \mathrm{~mm}$ and $0.39 \mu$ mo.d., Varian, USA) Select Fame. The column temperature was programmed at $165^{\circ} \mathrm{C}$ for 18 minutes, $180^{\circ} \mathrm{C}\left(30^{\circ} \mathrm{C}\right.$ min- 1$)$ for 22 minutes, and $240^{\circ} \mathrm{C}\left(15^{\circ} \mathrm{C}\right.$ min- 1$)$ for 30 minutes with 45 psi pressure. The injector and detector were kept at $220^{\circ} \mathrm{C}$ and $245^{\circ} \mathrm{C}$, respectively. The gas fluxes (White Martins) used were as follows: $1.4 \mathrm{~mL}$ min-1 for the carrier gas $\left(\mathrm{H}_{2}\right) ; 30 \mathrm{ml} \mathrm{min}-1$ for the make-up gas $\left(\mathrm{N}_{2}\right)$; and $30 \mathrm{~mL}$ min-1 and $300 \mathrm{~mL}$ min-1 for $\mathrm{H}_{2}$ and the synthetic flame gas, respectively. The sample injection split mode was 1/80. Fatty acids were identified by comparing the relative retention times of FAME peaks of the samples with fatty acids methyl ester standards from Sigma (USA) by spiking samples with the standard. The peak areas were determined by Star software (Varian). The data were expressed as percentages of the normalised area of fatty acids.

\section{Statistical analyses}

The data were analysed by the analysis of variance and the differences were evaluated using the Tukey test. The data were analysed by SAS (2003). 


\section{RESULTS AND DISCUSSION}

\section{Feedlot performance}

Final body weight and average daily gain were similar $(\mathrm{P}>0.05)$ between the bulls fed with 5 or $12 \%$ glycerin level in their diets but were higher $(\mathrm{P}<0.08)$ when compared to bulls that were fed no glycerin in their diets (Table 2). It has been reported that the inclusion of glycerin in Angus steer finishing diets resulted in improving the ADG by $11.4 \%$ when glycerin replaced $10 \%$ of the dry-rolled corn, but the ADG improved only $2.5 \%$ when glycerin replaced $10 \%$ of the dry-rolled corn in the diets that also contained 30\% distillers' dried grains and 15\% soy hulls (Pyatt et al. 2007). Parsons et al. (2009) observed that the ADG increased by $12.6,8.4$ and $5.0 \%$ for the heifers that were fed 2, 4 and $8 \%$ glycerin, respectively, but at 12 and $16 \%$ glycerin, the ADG was reduced by 1.7 and $13.4 \%$, respectively. However, Mach et al. (2009) did not observe glycerin level effects on ADG for Holstein bulls finished in feed-lot and fed with 4,8 or $12 \%$ glycerin levels in their diets. These results provided evidence that glycerin could be used as an energetic ingredient that could be effectively substitute for corn in the diets of finishing bulls. The present study indicated that some potentially negative glycerin components such as salt $(4.76 \%)$ and methanol $(0.33 \%)$ might not exert detrimental effects on the growth of the animal when glycerin was included in the diets of bulls.

No changes $(\mathrm{P}>0.05)$ in the DMI occurred when glycerin was included at 0,5 or $12 \%$ in the diet $(11.3,12.2$ and $11.1 \mathrm{~kg} /$ day) (Table 2). Similarly, Mach et al. (2009) reported no changes in the DMI when glycerin was included at $0,4,8$ or $12 \%$ in the diet $(8.3 \mathrm{~kg} /$ day $)$ in Holstein bulls that were fed high-concentrate diets. Ogborn (2006) reported that $5 \%$ glycerin increased the DMI in prepartum dairy cows. In contrast, Parsons et al. (2009) reported a $13 \%$ reduction in the DMI when glycerin was added at $16 \%$ to a steam-flaked corn fed to heifers for the final 85 days before the slaughter. Schröder and Südekum (1999) reported $0.7 \mathrm{~kg} /$ day reduction in starch intake in ruminally cannulated steers that were fed $15 \%$ glycerin. Some others studies conducted with lactating cows that were fed high-forage diets (DeFrain et al. 2004; Chung et al. 2007) have reported no negative effects on the feed intake when supplementing the diets with glycerin at inclusion rates similar to the present study. Feed efficiency was not affected $(\mathrm{P}>0.05)$ by glycerin level (Table 2 ). However, the feed efficiency improved by $10.8,10.0,7.2$ and $33.1 \%$ when glycerin was included at $2,4,8$, and $12 \%$ of the diet, respectively, but adding glycerin at $16 \%$ reduced this efficiency with 2.8\% (Parsons et al. 2009). Pyatt et al. (2007) reported a $21.9 \%$ improvement in the feed efficiency when glycerin replaced $10 \%$ of the dry-rolled corn in the diets.

\section{Carcass characteristics and meat quality}

The HCW increased $(\mathrm{P}<0.10)$ when glycerin was fed at $5 \%(285.1 \pm 6.73 \mathrm{~kg})$, but glycerin decreased the carcass final BW $(282.1 \pm 6.73 \mathrm{~kg})$ when fed at $12 \%$ (Table 3) in the diet. Mach et al. (2009) reported similar HCW data when feeding Holstein bulls high-concentrate diets in the feedlot. Including glycerin at up to $5 \%$ in the diet could effectively increase the HCW in finishing bulls. The HCW increased 8.1, 5.1, and $3.2 \mathrm{~kg}$ when glycerin was fed at 2, 4 or $8 \%$, respectively, but the $\mathrm{HCW}$ decreased 1.2 and $9.1 \mathrm{~kg}$ when glycerin was fed at 12 and $16 \%$ in the diet, respectively (Parsons et al. 2009).

The glycerin level did not affect $(\mathrm{P}<0.05)$ the dressing percentage $(54.9 \%$, Table 3 ). Likewise, Mach et al. (2009) reported similar carcass dressing data when feeding Holstein bulls highconcentrate diets to a final $\mathrm{BW}$ similar to that of the current study. The dressing percentage was within the range observed for the beef cattle slaughtered from 18 to 24 months and finished in feedlot with a high energy density diet (Prado et al. 2008d; 2009c; Rotta et al. 2009a; b). Thus, the inclusion of glycerin in the levels studied had no effect on the dressing percentage in beef cattle finished in feedlot.

Drip loss was similar $(\mathrm{P}>0.10)$ among the glycerin levels (Table 3 ). Thus, the addition of glycerin in the diet of cattle finished in feedlot did not alter the water loss during the chilling $\left(4^{\circ} \mathrm{C}\right)$ for $24 \mathrm{~h}$ as observed for the carcasses of monogastric animals (Mourot et al. 1994). Fat thickness was similar ( $>0.10)$ among the bulls that were fed different glycerin levels (Table 3). Mach et al. (2009) reported similar fat thickness data when feeding bulls high-concentrate diets and finishing in feedlot. The fat thickness noted in the bulls met the guidelines of the Brazilian market, which required the carcass to have between 3 and $6 \mathrm{~mm}$ of fat thickness. Thus, these bulls presented the minimum thickness required for favourable marketing. 
Table 3 - Carcass characteristics of Nellore bulls finished in feed-lot fed diets containing different glycerin level.

\begin{tabular}{llllll}
\hline \multirow{2}{*}{\multicolumn{1}{c}{ Item }} & \multicolumn{3}{c}{ Dietary glycerin, \% } \\
\cline { 2 - 6 } & $\mathbf{G 0 0}^{\mathbf{1}}$ & $\mathbf{G 0 5}^{\mathbf{2}}$ & $\mathbf{G 1 2}^{\mathbf{3}}$ & $\mathbf{S D}^{\mathbf{4}}$ & $\mathbf{P < F}^{\mathbf{5}}$ \\
\hline Hot carcass weight, $\mathrm{kg}$ & $280.8 \mathrm{~b}$ & $285.1 \mathrm{a}$ & $282.1 \mathrm{ab}$ & 6.73 & 0.10 \\
Cold carcass weight, $\mathrm{kg}$ & $276.4 \mathrm{~b}$ & $280.4 \mathrm{a}$ & $277.6 \mathrm{~b}$ & 6.71 & 0.10 \\
Dressing percentage, \% & 54.8 & 55.0 & 54.7 & 0.48 & 0.25 \\
Drip loss, \% & 1.61 & 1.66 & 1.59 & 0.07 & 0.23 \\
Fat thickness, mm & 3.42 & 3.31 & 3.94 & 0.51 & 0.12 \\
Longissimus muscle, cm ${ }^{2}$ & $65.2 \mathrm{~b}$ & $67.1 \mathrm{ab}$ & $69.8 \mathrm{a}$ & 2.29 & 0.04 \\
Conformation, points & 12.5 & 13.0 & 12.6 & 0.38 & 0.23 \\
Color, points & 3.70 & 3.38 & 3.88 & 0.25 & 0.26 \\
Texture, points & 4.33 & 4.38 & 4.38 & 0.18 & 0.62 \\
Marbling, points & 5.08 & 4.50 & 5.13 & 0.54 & 0.36 \\
pH & 6.18 & 6.35 & 6.11 & 0.09 & 0.45 \\
Thawing loss, \% & 5.44 & 5.31 & 5.19 & 1.25 & 0.38 \\
Cooking loss, \% & 28.9 & 25.1 & 27.4 & 2.40 & 0.26 \\
\hline
\end{tabular}

${ }^{1}$ Without glycerin; ${ }^{2} 5 \%$ glycerin; ${ }^{3} 12 \%$ glycerin; ${ }^{4}$ Standard deviation; ${ }^{5}$ Effect of glycerin level.

The Longissimus muscle $(\mathrm{LM})$ increased $(\mathrm{P}<0.10)$ when glycerin was fed at $12 \%$ of the diet $(69.8$ $\mathrm{cm}^{2}$ ) in comparison with the diet without glycerin (Table 3). Mach et al. (2009) reported similar LM area data when feeding the Holstein bulls in feedlot. However, Parsons et al. (2009) observed that LM significantly increased when glycerin was fed at $2 \%$ of the diet, but a linear reduction in the LM area occurred with increasing amounts of glycerin.

Dietary treatments did not affect $(\mathrm{P}>0.05)$ the conformation, colour, texture or marbling of the meat (Table 3). Mach et al. (2009) reported similar carcass quality data when feeding the Holstein bulls high-concentrate diets to a final body weight similar to that of the current study. Our data indicate that in finishing diets, glycerin concentrations up $12 \%$ were optimal for desired carcass characteristics as observed by Parsons et al. (2009) for crossbred heifers finished in feedlot. The $\mathrm{pH}$ in the LM of bulls was similar $(\mathrm{P}>0.05)$ among the diets (Table 3). However, the $\mathrm{pH}$ was very elevated for the bulls slaughtered in this experiment. The truck stocking density was only 1 animal $/ \mathrm{m}^{2}$ and transport distance was short $(80$ $\mathrm{km})$. At the slaughterhouse, bulls were housed in collective pens for approximately $12 \mathrm{~h}$ (overnight) before the slaughter.

Dietary glycerin may reduce water loss from the carcass if harvest follows an overnight fast (Mourot et al. 1994). In the current study, however, LM water loss was not affected by the diet (Table 3). Furthermore, the data presented here indicated that water loss were not affected by the crude glycerin supplementation, which was in contrast with the findings of Morout et al. (1994), who reported lower carcass drip and cooking loss from the muscle of the pigs that were fed 5\% glycerin in their diet. The addition of glycerin in the diet of cattle did not affect $(\mathrm{P}>0.10)$ lightness, red and yellow intensities of the LM (Table 4).

The lightness is influenced by the amount of water on the surface of the part, which is a consequence of water retention capacity; this, in turn, affects the $\mathrm{pH}$.

Likewise, the levels of glycerin in the diet did not alter shear force before or after cooking the meat (Table 4). The obtained WBSF results $(<4.0 \mathrm{~kg})$ ensure a tenderness that should result in high consumer acceptance (Miller et al. 2001).

Table 4 - Lightness (L), red intensity ( $a^{*}$ ), yellow intensity ( $\left.b^{*}\right)$, shear force before cooking (SFBC) and shear force after cooking (SFAC) on Longissimus muscle of Nellore bulls finished in feed-lot fed diets containing different glycerin levels.

\begin{tabular}{llllll}
\hline & \multicolumn{3}{c}{ Dietary glycerin, DM/\% } & & \\
\cline { 2 - 6 } Item & $\mathbf{G 0 0}^{\mathbf{1}}$ & $\mathbf{G 0 5}^{\mathbf{2}}$ & $\mathbf{G 1 2}^{\mathbf{3}}$ & $\mathbf{S D}^{\mathbf{4}}$ & $\mathbf{P}^{\mathbf{5}} \mathbf{F}^{\mathbf{3}}$ \\
\hline $\mathrm{L}$, points & 32.1 & 31.4 & 33.7 & 0.91 & 0.68 \\
$\mathrm{a}^{*}$, points & 12.2 & 12.8 & 13.3 & 0.58 & 0.36 \\
$\mathrm{~b}^{*}$, points & 4.32 & 4.05 & 4.97 & 0.42 & 0.27 \\
SFBC, $\mathrm{kg} / \mathrm{cm}^{2}$ & $4.34 \mathrm{~b}$ & $5.53 \mathrm{a}$ & $4.19 \mathrm{~b}$ & 3.97 & 0.05 \\
SFAC, $\mathrm{kg} / \mathrm{cm}^{2}$ & 9.08 & 10.1 & 10.4 & 1.01 & 0.37 \\
\hline
\end{tabular}

${ }^{\mathrm{T}}$ Without glycerin; ${ }^{2} 5 \%$ glycerin; ${ }^{3} 12 \%$ glycerin; ${ }^{4}$ Standard deviation; ${ }^{5}$ Effect of glycerin level. 


\section{Chemical composition}

There was difference $(\mathrm{P}>0.05)$ in the moisture, ashes and crude protein between glycerin levels (Table 5).

The mean values of the moisture, ashes and crude protein were $74.1,1.09 \%$ and $21.6 \%$, respectively. These results were similar to the results presented by Prado et al. (2009a; b; c), Rotta et al. (2009a; b), who studied the chemical composition of different genetic groups, nutrition, finishing systems and gender of the cattle finished in the feedlot and pasture. According to these results, the moisture, ashes and crude protein values did not suffer variations due to glycerin levels.

There was variation in the percentage of the lipids due to glycerin levels (Table 5). Bulls that received $12 \%$ glycerin in their diets presented the higher $(\mathrm{P}<0.03)$ percentage for the total lipids in LM $(1.53 \%)$. In the present study, it was hypothesised that glycerin supplementation would reduce the acetate to propionate ratio in the rumen, mainly resulting from an increase in rumen molar proportions of propionate, which was a glucose precursor. In addition, glycerin could be converted to glucose in the liver of cattle. Thus, it was expected that glucose supply would increase in the bulls supplemented with glycerin, fostering a rise in blood insulin concentrations and lipogenesis. In fact, bulls receiving $12 \%$ glycerin treatment had the numerically highest intramuscular fat content. Some studies (Purchas et al. 2002; Mach et al. 2009; Pedrão et al. 2009) have associated the tenderness with intramuscular fat content. However, the percentage of total lipids observed in the samples from the animals that were fed different glycerin levels was below the maximum level $( \pm 5 \%)$, which was regarded as acceptable for the prevention of diseases related to fat content in beef, according to recommendations from the England Health Department (HMSO, 1994).

The proportion of fatty acids in the intramuscular fat is shown in Table 6 . The diversity of fatty acids was partly explained by biohydrogenation reactions in the rumen (Tamminga and Doreau,
1991). The myristic acid (14:0), palmitoleic acid $(16: 1 n-7)$ and $\alpha$-linolenic acid (18:3 n-3) were higher $(\mathrm{P}<0.05)$ in the muscles of the bulls fed with glycerin in their diet. In contrast, the pentadecilic acid (15:0) and timnodonic acid (C:25 $n$-3) were lower $(\mathrm{P}<0.05)$ in the muscles of the bulls fed without glycerin in their diet. The percentage of other fatty acids was similar $(\mathrm{P}>0.05)$ with or without glycerin addition in the diets. There was no clear consensus on the effect that feeding crude glycerin might have on the fatty acid profile of lipids in the cattle. The apparent disagreement about the effect that feeding glycerin had on the fatty profile of cattle could be due to the differences in the amount and profile of fatty acids remaining in the crude glycerin or, in the present case, the reduction in corn (and consequently corn oil) due to the addition of crude glycerin. The relative differences in the amounts and profiles of fatty acids in other feedstuffs included in the experimental diets might also limit the comparison across the diets.

The percentage of saturated fatty acids (SFA), monounsaturated acids (MUFA), polyunsaturated acids (PUFA), $n-6$ and $n-3$ fatty acids as well as the MUFA/SFA and $n-6: n-3$ ratios of the LM are presented in Table 7.

Most of the identified fatty acids were saturated and did not differ $(\mathrm{P}<0.05)$ among the diets. The MUFA were present in the second highest concentration and were not affected $(\mathrm{P}>0.05)$ by the addition of glycerin to the diet. Aricetti et al. (2008); Prado et al. (2008a; b) and Prado et al. (2009a; b; c) observed similar percentages of the SFA and MUFA in the bulls from different crossbreeding systems that were finished under similar diets and handled as in this experiment. Thus, the SFA and MUFA percentages varied little as a function of the diet. The PUFA percentage was $7.1 \%$. Similar values were found in the LM of bulls finished in a feedlot (Aricetti et al. 2008; Prado et al. 2008a; b; Prado et al. 2009a; b; c; Rotta et al. 2009a; b).

Table 5 - Chemical composition on Longissimus muscle of Nellore bulls finished in feed-lot fed diets containing different glycerin levels.

\begin{tabular}{llllll}
\hline & \multicolumn{2}{l}{ Dietary glycerin, DM/\% } & & \\
\cline { 2 - 5 } Item & $\mathbf{G 0 0}$ & $\mathbf{G 0 5}^{\mathbf{2}}$ & $\mathbf{G 1 2}^{\mathbf{3}}$ & $\mathbf{S D}^{\mathbf{4}}$ & ${\mathbf{P}<\mathbf{F}^{\mathbf{5}}}$ \\
\hline Moisture, \% & 74.1 & 74.4 & 74.1 & 0.95 & NS \\
Ashes, \% & 1.09 & 1.08 & 1.10 & 0.05 & NS \\
Crude protein, \% & 21.5 & 21.6 & 21.7 & 0.85 & NS \\
Total lipids, \% & $1.12 \mathrm{~b}$ & $0.91 \mathrm{~b}$ & $1.53 \mathrm{a}$ & 0.25 & 0.03 \\
\hline
\end{tabular}

${ }^{\mathrm{T}}$ Without glycerin; ${ }^{2} 5 \%$ glycerin; ${ }^{3} 12 \%$ glycerin; ${ }^{4}$ Standard deviation; ${ }^{5}$ Effect of glycerin level. 
Table 6 - Fatty acid profile on muscle Longissimus of Nellore bulls finished in feedlot fed diets containing different glycerin levels.

\begin{tabular}{|c|c|c|c|c|c|}
\hline \multirow{2}{*}{ Fatty acids ${ }^{1}$} & \multicolumn{5}{|c|}{ Dietary glycerin, DM/\% } \\
\hline & $\mathrm{G00}^{2}$ & $\mathrm{G05}^{3}$ & G12 $^{4}$ & SD $^{5}$ & $\mathbf{P}<\mathbf{F}^{6}$ \\
\hline $14: 0$ & $1.76 \mathrm{~b}$ & $1.96 \mathrm{~b}$ & $2.62 \mathrm{a}$ & 0.25 & 0.10 \\
\hline $14: 1(n-7)$ & 0.10 & 0.14 & 0.13 & 0.03 & 0.10 \\
\hline $15: 0$ & $0.25 \mathrm{a}$ & $0.14 b$ & $0.10 \mathrm{~b}$ & 0.01 & NS \\
\hline $16: 0$ & 25.7 & 26.3 & 27.2 & 1.66 & 0.13 \\
\hline $16: 1(n-7)$ & $2.30 \mathrm{~b}$ & $2.42 b$ & $2.92 \mathrm{a}$ & 0.17 & 0.10 \\
\hline 17:0 & 0.39 & 0.42 & 0.44 & 0.03 & NS \\
\hline $17: 1(n-7)$ & 0.75 & 0.87 & 0.84 & 0.04 & NS \\
\hline $18: 0$ & 19.9 & 20.2 & 17.8 & 1.54 & NS \\
\hline $18: 1(n-9)$ & 40.5 & 39.7 & 39.9 & 2.11 & NS \\
\hline $18: 1(n-7)$ & 0.20 & 0.19 & 0.25 & 0.03 & NS \\
\hline $18: 2(\mathrm{n}-6)$ & 4.19 & 3.60 & 3.47 & 0.25 & NS \\
\hline $18: 2(\mathrm{c}-9 \mathrm{t}-11)$ & 0.09 & 0.10 & 0.10 & 0.02 & NS \\
\hline $18: 3(n-6)$ & 0.51 & 0.59 & 0.62 & 0.02 & NS \\
\hline $18: 3(n-3)$ & $0.22 b$ & $0.26 \mathrm{a}$ & $0.28 \mathrm{a}$ & 0.01 & 0.05 \\
\hline $20: 3(n-3)$ & 0.24 & 0.23 & 0.22 & 0.01 & NS \\
\hline $20: 4(\mathrm{n}-6)$ & 0.99 & 1.09 & 1.05 & 0.02 & NS \\
\hline $20: 5(n-3)$ & $0.26 \mathrm{a}$ & $0.12 b$ & $0.13 b$ & 0.02 & 0.05 \\
\hline $22: 0$ & 0.12 & 0.12 & 0.13 & 0.04 & NS \\
\hline $22: 1(n-9)$ & 0.10 & 0.10 & 0.11 & 0.05 & NS \\
\hline $22: 4(n-6)$ & 0.32 & 0.30 & 0.34 & 0.03 & NS \\
\hline $22: 6(n-3)$ & 0.86 & 0.82 & 0.90 & 0.10 & NS \\
\hline
\end{tabular}

${ }^{1}$ Fatty acids are expressed as $\mathrm{g} / 100 \mathrm{~g}$ total fatty acids. Fatty acids are designated by the number of carbon atoms followed by the number of double bonds. The position of the first double bond relative to the methyl (n) end of the molecule is also included. ${ }^{2}$ Without glycerin; ${ }^{3} 5 \%$ glycerin; ${ }^{4} 12 \%$ glycerin; ${ }^{5}$ Standard deviation; ${ }^{6}$ Effect of glycerin level.

Table 7 - Fatty acid sum of saturated (SFA), monounsaturated (MUFA), polyunsaturated (PUFA), fatty acids $n$-6, fatty acids n-3, PUFA:MUFA and n-6:n-3 ratio on Longissimus muscle of Nellore bulls finished in feedlot fed diets containing different glycerin levels.

\begin{tabular}{llllll}
\hline & \multicolumn{5}{c}{ Dietary glycerin, DM/\% } \\
\cline { 2 - 6 } Item & $\mathbf{G 0 0}^{\mathbf{1}}$ & $\mathbf{G 0 5}^{\mathbf{2}}$ & $\mathbf{G 1 2}^{\mathbf{3}}$ & $\mathbf{S D}^{\mathbf{4}}$ & $\mathbf{P}^{\mathbf{5}}$ \\
\hline SFA & 47.6 & 49.7 & 48.9 & 1.36 & NS \\
MUFA & 44.7 & 43.6 & 44.3 & 1.54 & NS \\
PUFA & 7.69 & 6.68 & 6.79 & 0.78 & NS \\
$n 6$ & 4.03 & 3.74 & 3.53 & 0.66 & NS \\
$n 3$ & 1.53 & 1.39 & 1.53 & 0.09 & NS \\
PUFA/SFA & 0.17 & 0.13 & 0.14 & 0.03 & NS \\
$n 6 / n 3$ & 2.63 & 2.70 & 2.31 & 0.57 & NS \\
\hline
\end{tabular}

${ }^{1}$ Without glycerin; ${ }^{2} 5 \%$ glycerin; ${ }^{3} 12 \%$ glycerin; ${ }^{4}$ Standard deviation; ${ }^{5}$ Effect of glycerin level.

No difference was observed $(\mathrm{P}>0.05)$ for the PUFA:SFA ratio among the diets, with an average of 0.15 . The PUFA:SFA ratio found in this study was below the value of 0.45 recommended by the England Department of Health (HMSO, 1994), which was considered beneficial to the human health. The low PUFA:SFA ratio could be explained by the biohydrogenation process undergone by the dietary unsaturated fatty acids in the rumen by microorganisms. No difference was observed $(\mathrm{P}>0.05)$ for the $n-6: n 3$ ratio among the diets, with an average of 2.5 (Table 7). According to the England Department of Health (HMSO, 1994), the recommended $n-6: n-3$ ratio is $4: 1$. Thus, the observed values in this study were low when compared to the ideal.

During the course of this study, no bull demonstrated any clinical signs of methanol toxicity. Current biodiesel processing techniques utilise methanol, which is not completely recovered, and thus, methanol is found in the crude glycerin at very low concentrations $(0.33 \%)$. Intermediates in the metabolism of methanol to carbon dioxide and water are formaldehyde and formate. The toxic effects due to methanol poisoning are actually due to the formation, accumulation, and slow metabolism of formate in some species (Skrzydlewska 2003). The clinical 
consequences of methanol poisoning are central nervous system depression, vomiting, severe metabolic acidosis, blindness, and a Parkinson-like motor disease (Skrzydlewska, 2003).

\section{CONCLUSIONS}

The results from this study demonstrated that up to $12 \%$ crude glycerin could be fed to the finishing bulls with little or no effect on the growth performance, carcass composition or meat quality. Although there was only small effect on the performance and fatty acid profiles of the LM, the effect of crude glycerin supplementation on the quality of the meat through the evaluation of the amount, method, or length of administration might warrant further examination. It was concluded that crude glycerin could be a viable source of dietary energy that was well-utilised by the bulls. Lastly, although this study was not designed to specifically examine the toxicology of methanol fed to the bulls, the results indicated that the concentration of methanol in these diets did not negatively affect the performance of the bull and carcass characteristics.

\section{ACKNOWLEDGMENTS}

This project was supported by the Araucaria Foundation, State of Paraná funds and the Brazilian Council for Research and Technological Development $(\mathrm{CNPq})$. The authors gratefully acknowledge the Processing Inc. (BIOPAR, Paraná, Rolândia, Brazil South) for providing the crude glycerine used in this study. The mention of trade names or commercial products in this publication is solely for the purpose of providing specific information and does not imply recommendations or endorsement by the Department of Animal Science, Maringá State University, Paraná and South Brazil.

\section{REFERENCES}

Abrahão JJ, Prado IN, Marques JA, Perotto D, Lugão SM. Effects of replacing corn with dry cassava byproduct on production of feedlot crossbred heifers. Braz J Anim Sci. 2006; 35(2):512-518.

Abrahão JJS, Prado IN, Perotto D, Moletta JL. Effects of replacing corn with increasing levels of cassava starch by-products on carcass characteristics and meat for young bulls. Braz J Anim Sci. 2005; 34(5):1640-1650.

Aricetti JA, Rotta PP, Prado RM, Perotto D, Moletta JL, Matssushita $M$ et al. Carcass characteristics, chemical composition and fatty acid profile of Longissimus muscle of bulls and steers finished in a pasture system. Asian Austral J Anim Sci. 2008; 21(10):1441-48.

Association of Official Analytical Chemists - AOAC. Official methods of analysis. $14^{\text {ed. }}$ Arlington, V.A. 1998, 1094p.

Bligh EG, Dyer WJ. A rapid method of total lipid extraction and purification. Can J Bioch Physiol. 1959; 37(8):911-17.

Bouton PE, Harris PV, Shorthose WR. Effect of ultimate $\mathrm{pH}$ upon the water-holding capacity and tenderness of mutton. J Food Sci. 1971; 36(3):435-9.

Chung YH, Rico DE, Martinez CM, Cassady TW, Noirot $\mathrm{N}$, Ames A et al. Effects of feeding dry glycerine to early postpartum Holstein dairy cows on lactation performance and metabolic profiles. J Dairy Sci. 2007; 90(12):5682-91.

CIOMS/OMS. Council for International Organizations of Medical Services. WHO Distribution and sales service, 1985, 1211 Geneva 27, Switzerland, International Guiding Principles for Biomedical Research Involving Animals, 1985.

Dasari MA, Kiatsimkul PP, Sutterlin RW, Suppes GJ. Low-pressure hydrogenolysis of glycerine to propylene glycol. App. Catal.: A General. 2005; 281(1-2):225-31.

DeFrain JM, Hippen AR, Kalscheur KF, Jardon PW. Feeding glycerine to transition dairy cows: Effects on blood metabolites and lactation performance. 2004; $J$ Dairy Sci. 87(12):4195-4206.

Donkin SS. Glycerine from biodiesel production: the new corn for dairy cattle. Braz J Anim Sci. 2008; 37(Esp):280-286.

Elam NA, Eng KS, Bechtel B, Harris JM, Crocker R. Glycerine from Biodiesel Production: Considerations for feedlot diets. Proceedings of the Southwest Nutrition Conference. Tempe AZ, 2008.

England Department of Health. Nutritional aspects of cardiovascular disease. London: HMSO, p. 37-46. (Report on Health and Social Subjects, 46); 1994.

Hippen AR, DeFrain JM, Linke PL. Glycerine and other energy sources for metabolism and production of transition dairy cows. Florida Ruminant Nutrition Symposium, January 29-30; 2008.

Honikel KO. Reference methods for the assessment of physical characteristics of meat. Meat Sci. 1998; 49(4):447-57.

ISO - International Organization for Standardization. Animal and vegetable fats and oils - Preparation of methyl esters of fatty acids. Method ISO 5509; 1978.

Laboratório Nacional De Referência Animal. Métodos oficiais para controle de produtos de origem animal $e$ seus ingredientes. Brasília, DF. LANARA; 1981.

Mach N, Bach A, Devant M. Effects of crude glycerine supplementation on performance and meat quality of Holstein bulls fed high-concentrate diets. J Anim Sci. 2009; 87(2):632-638. 
Miller M, Carr M, Ramsey C, Crocket K, Hoover L. Consumer thresholds for establishing the value of beef tenderness. J Anim Sci. 2001; 79(12):3062-68.

Moreira FB, Souza NE, Matsushita M, Prado IN, Nascimento WGN. Evaluation of carcass characteristics and meat chemical composition of Bos indicus and Bos indicus $\mathrm{x}$ Bos Taurus crossbred steers finished in pasture system. Braz. Arch. Biol. Techon. 2003; 46(4):609-16.

Mourot J, Aumaitre A, Mounier A, Peiniau P, Fraçois AC. Nutritional and physiological effects of dietary glycerine in the growing pig: Consequences on fatty tissues and post mortem muscular parameters. Livest Prod Sci. 1994; 38:239-44.

Müller L. (1980). Normas para avaliação de carcaças $e$ concurso de carcaça de novilhos. Santa Maria, Imprensa Universitária, 31p.

Ogborn KL. Effects of method of delivery of glycerine on performance and metabolism of dairy cows during the transition period. MS Thesis. Cornell University, Ithaca, NY; 2006.

Oliveira JS, Queiroz AC, Lana RP, Mantovani HC, Generoso RAR. Effects of monensin and bee propolis on in vitro fermentation of amino acids by mixed ruminal bacteria. Braz J Anim Sci. 2006; 35(1):275-81.

Ooi TL, Yong KC, Hazimah AH, Dzulkefly K, WanYunus WMZ. Glycerine Residue - A Rich Source of Glycerine and Medium Chain Fatty Acids. J Oleo Sci. 2004; 53(1):29-33.

Parsons GL, Shelor MK, Drouillard JS. Performance and carcass traits of finishing heifers fed crude glycerine. $J$ Anim Sci. 2009; 87(2):653-57.

Pedrão MR, Lassance F, Souza NE, Matsushita M, Telles $\mathrm{P}$, Shimokomaki M. Comparison of proximate chemical composition and texture of cupim, Rhomboideus $m$. and lombo, Longissimus dorsi $\mathrm{m}$. of Nellore (Bos indicus). Braz Arch Biol Techon. 2009; 52(3):715-20.

Prado IN, Moreira FB, Matsushita M, Souza NE. Longissimus dorsi fatty acids composition of Bos indicus and Bos taurus crossbred steers finished in pasture. Braz Arch Biol Techon. 2003; 46(4):601-08.

Prado IN, Aricetti JA, Rotta PP, Prado RM, Perotto D, Visentainer JV et al. Carcass characteristics, chemical composition and fatty acid profile of the Longissimus muscle of bulls (Bos Taurus indicus vs. Bos Taurus taurus) finished in pasture systems. Asian Austral $J$ Anim Sci. 2008a; 21(10):1449-57.

Prado IN, Ito RH, Prado JM, Prado IM, Rotta PP, Matsushita $\mathrm{M}$ et al. The influence of dietary soyabean and linseed on the chemical composition and fatty acid profile of the Longissimus muscle of feedlot-finished bulls. J Anim Feed Sci. 2008b; 17:307-17.

Prado IN, Prado RM, Rotta PP, Visentainer JV, Moletta JL, Perotto D. Carcass characteristics and chemical composition of the Longissimus muscle of crossbred bulls (Bos Taurus indicus vs. Bos Taurus taurus) finished in feedlot. J Anim Feed Sci. 2008c; 17:295-306.

Prado IN, Rotta PP, Prado RM, Visentainer JV, Moletta JL, Perotto D. Carcass characteristics and chemical composition of the Longissimus muscle of Purunã and 1/2
Purunã vs. 1/2 Canchin bulls meat quality of bulls. Asian Austral J Anim Sci. 2008d; 21(9):1296-1302.

Prado IN, Oliveira AN, Rotta PP, Perotto D, Prado RM, Silva RR et al. Chemical and fatty acid composition of Longissimus muscle of crossbred bulls finished in feedlot. Asian Austral J Anim Sci. 2009a; 22(7):1054-59.

Prado IN, Visentainer JV, Rotta PP, Perotto D, Moletta JL, Prado RM et al. The effect of breed on the chemical composition and fatty acid profile of the Longissimus dorsi muscle of Brazilian beef cattle. J Anim Feed Sci. 2009b; 18:231-40.

Prado RM, Prado IN, Marques JA, Rotta PP, Visentainer JV, Silva RR et al. Meat quality of the Longissimus muscle of bulls and steers ( $1 / 2$ Nellore vs. $1 / 2$ Simmental) finished in feedlot. J Anim Feed Sci. 2009c; 18:221-30.

Purchas RW, Burnham DL, Morris ST. Effects of growth potential and growth on tenderness of beef Longissimus muscle from bulls and steers. J Anim Sci. 2002; 80(12):3211-21.

Pyatt AP, Doane PH, Cecava MJ. Effect of crude glycerine in finishing cattle diets. J Anim Sci; 85(Suppl. 1):530 (Abstract); 2007.

Rotta PP, Prado IN, Prado RM, Moletta JL, Silva RR, Perotto D. Carcass characteristics and chemical composition of the Longissimus muscle of Nellore, Caracu and Holstein-friesian bulls finished in a feedlot. Asian Austral J Anim Sci. 2009a; 22(4):598-604.

Rotta PP, Prado R.M, Prado IN, Valero, MV, Visentainer JV, Silva RR. The effects of genetic groups, nutrition, finishing systems and gender of Brazilian cattle on carcass characteristics and beef composition and appearance: a review. Asian Austral J Anim Sci. 2009b; 22(12):1718-34

Schröder A, Südekum KH. Glycerine as a byproduct of biodiesel production in diets for ruminants. In: Wratten, N.; Salisbury, P.A. (Eds.), New Horinzons for an Old Crop. Proc. $10^{\text {th }}$ Int. Rapessed Congr., Canberra, Australia, Paper No. 241. The Regional Institute Ltd., Gosford, New South Wales, Australia. 1999.

Skrzydlewska E. Toxicological and metabolic consequences of methanol poisoning. Toxicol Mechan Methods. 2003; 13(4):277-93.

Statistical Analysis System. SAS/STAT® (2003), User's guide: statistics, version $8.1 .4^{\text {ed }}$. Cary: SAS Institute, v. 2.

Tamminga S, Doreau M. Lipids and rumen digestion. In: J.P. Jouany (Ed), Rumen microbial metabolism and ruminant digestion, Paris: INRA, p. 151-164. 1991.

Trabue S, Scoggin K, Tjandrakusuma S, Rasmussen MA, Reilly PJ. Ruminal fermentation of propylene glycol and glycerine. J Agric Food Chem. 2007; 55(17):7043-51.

Received: July 06, 2011; Revised: March 22, 2012; Accepted: December 17, 2012. 